\title{
PAJAK ATAS JASA BIDANG PERHOTELAN
}

\author{
Retnaningtyas Widuri \\ Fakultas Ekonomi Universitas Kristen Petra \\ e-mail: widuri@peter.petra.ac.id
}

\begin{abstract}
Abstrak: Tulisan ini ingin menguraikan aturan pajak yang berlaku saat ini untuk sektor jasa perhotelan di Indonesia yang ditetapkan oleh pemerintah pusat dan pemerintah daerah. Meskipun secara substansi jasa perhotelan mirip dengan jasa penyewaan ruangan, namun perlu dibedakan antara jasa penyewaan kamar dengan jasa penyewaan ruangan untuk toko ataupun kantor. Jasa penyewaan kamar dianggap sebagai kegiatan yang berhubungan dengan jasa di bidang perhotelan, dan dikenakan pajak hotel dan restoran sesuai dengan aturan pemerintah daerah. Sedangkan jasa penyewaan ruangan untuk toko atau kantor akan dikenakan pajak penghasilan final dan atas pengguna jasa tersebut harus dipungut pajak pertambahan nilai
\end{abstract}

Kata kunci: Jasa Bidang Perhotelan, Pajak Daerah, Pajak Pertambahan Nilai, Pajak Penghasilan.

\begin{abstract}
This article is to describe the current tax legislation applied for hotel business, which is governed by central authority and municipal or local authority. In substance, hotel services is similar with space rent services, although it should be clear whether it was a room rent services or space rent services for shops and offices. Room rent services is included in hotel services, hence, the municipal tax of hotel and restaurant will be applied on this kind of income. While income from space rent services for shops or offices is subject to final income tax and value added tax.
\end{abstract}

Keywords: Hotel Business Services, Hotel and Restaurant Tax, Final Income Tax, Value Added Tax.

Dalam praktik perpajakan yang tengah hangat didengungkan oleh hampir seluruh lapisan masyarakat, perbedaan persepsi masyarakat bukanlah hal yang tidak mungkin. Seringkali suatu aturan pajak mudah dipahami dan diaplikasikan dengan benar, namun tidak jarang dapat menimbulkan persepsi yang berbeda apabila terdapat kata atau kalimat yang mempunyai kemiripan namun ternyata mempunyai perlakuan yang berbeda. Inilah yang akan coba dikupas dalam artikel berikut sehubungan dengan jasa sewa dalam bidang perhotelan

\section{DEFINISI PAJAK}

Definisi Pajak atau pengertian pajak menurut Prof. Dr. Rochmat Soemitro, SH.:

Pajak adalah iuran rakyat kepada kas negara berdasarkan undang-undang (yang dapat dipaksakan) dengan tiada mendapat jasa timbal (kontraprestasi) yang langsung dapat ditunjukkan dan yang digunakan untuk membayar pengeluaran umum.

Dari definisi diatas, pajak memiliki unsur-unsur penting yaitu iuran dari rakyat kepada negara, berdasarkan undang-undang, tanpa kontrapretasi secara langsung dari negara dan digunakan untuk membayar pengeluaran umum yang bermanfaat bagi masyarakat luas.
Ditinjau dari segi hukum, pajak adalah perikatan yang timbul karena undang-undang yang mewajibkan seseorang untuk memenuhi syarat-syarat yang ditentukan oleh undang-undang untuk membayar sejumlah uang kepada Negara yang dapat dipaksakan, tanpa mendapatkan suatu imbalan yang secara langsung dapat ditunjuk, yang digunakan untuk membiayai pengeluaran-pengeluaran Negara (pengeluaran rutin dan pengeluaran pembangunan) dan yang digunakan sebagai alat untuk mencapai tujuan diluar bidang keuangan.

Pajak di Indonesia secara administratif dapat dibedakan berdasarkan golongan, sifat, dan lembaga pemungutnya.

Menurut golongannya, pajak dibagi atas pajak langsung dan tidak langsung. Dasar penggolongan langsung dan tidak ini sehubungan dengan pembebanan kepada wajib pajaknya,misal Pajak peghasilan, ataukah dapat dibebankan dialihkan kepada orang lain, misal Pajak Pertambahan Nilai. Dalam hal Pajak hotel, Wajib Pajak untuk pajak hotel adalah orang atau badan yang membayar atas pelayanan hotel dan pengusaha hotel. Sesuai dengan Peraturan Pemerintah No. 65 Tahun 2001 tentang Pajak daerah yang dimaksud sebagai Wajib Pajak hotel hanya pengusaha hotel. Padahal secara logika baik pembayar jasa hotel maupun pengusaha hotel merupakan wajib pajak dimana pembayar jasa hotel merupakan wajib pajak tidak langsung, sedangkan 
bagi pengusaha hotel merupakan wajib pungut. Pengusaha hotel berkewajiban menyetorkan pajak hotel ini ke Kas Daerah.

Pajak apabila ditinjau dari sifatnya, dibedakan menjadi pajak subyektif dan pajak obyektif. Jenis pajak subyektif adalah pajak yang berpangkal atu berdasarkan pada subjeknya, dalam arti memperhatikan keadaan diri wajib pajak. Misalnya pajak penghasilan, dalam pajak penghasilan keadaan diri wajib pajak apakah berupa pribadi atau badan,menjadi pertimbangan dalam pengenaan pajak. Namun berbeda halnya pada pajak obyektif, dimana keadaan wajib pajak tidak menjadi menjadi perhatian dan hanya memperhatikan objeknya saja. Misalnya Pajak Pertambahan Nilai, dalam pengenaannya tidak mempertimbangkan siapa yang akan membayar (WP pribadi atau Badan) melainkan hanya kepada obyeknya saja, misalnya barang atau jasanya.

Dalam hal ini pajak hotel, dimana dasar pengenaan pajak yang dimaksud adalah pembayaran atas pelayanan yang disediakan hotel, jadi pajak dikenakan atas setiap penggunaan jasa atau fasilitas yang disediakan hotel tanpa memperhatikan kondisi wajib pajak, maka dapat disimpulkan bahwa pajak hotel merupakan Pajak obyektif.

Penggolongan selanjutnya adalah berdasarkan lembaga pemungutnya, dimana pajak digolongkan menjadi Pajak Pusat dan Pajak Daerah. Pada hakekatnya tidak ada perbedaan pengertian yang pokok antara Pajak Negara dan Pajak Daerah mengenai prinsip-prinsip umum hukumnya. Perbedaan yang ada hanya pada aparat pemungut dan penggunaannya. Melihat nama pajaknya, tentu kita sudah dapat memaknai bahwa pajak pusat adalah pajak yang dipungut oleh pemerintah pusat dan digunakan untuk membiayai rumah tangga negara. Pajak yang termasuk dalam Pajak Pusat ini antara lain adalah Pajak Penghasilan (PPh), Pajak Pertambahan Nilai dan Pajak Penjualan atas Barang Mewah (PPN dan PPNBM), Pajak Bumi dan Bangunan (PBB) dan Bea Materai. Sedangkan Pajak Daerah merupakan pajak yang dipungut oleh pemerintah daerah dan untuk membiayai rumah tangga daerah. Sesuai dengan UU no 28 tahun 2009 mengenai Pajak Daerah dan Restribusi Daerah, Pajak Daerah dibagi menjadi Pajak Provinsi dan Pajak Kabupaten/Kota. Pajak yang termasuk dalam Pajak Daerah (Provinsi) adalah Pajak Kendaraan Bermotor; Pajak Bahan Bakar Kendaraan Bermotor; Pajak Air Permukaan; dan Pajak Rokok sedangkan yang termasuk dalam Pajak Daerah (Kabupaten/Kota) adalah Pajak Hotel; Pajak Restoran; Pajak Hiburan; Pajak Reklame; Pajak Penerangan Jalan; Pajak Mineral Bukan Logam dan Batuan; Pajak Parkir; Pajak Air Tanah; Pajak Sarang Burung Walet;
Pajak Bumi dan Bangunan Perdesaan dan Perkotaan; dan Bea Perolehan Hak atas Tanah dan Bangunan.

Sehubungan dengan penggolongan pajak berdasarkan lembaga pemungutnya, dalam pasal 4 Undang-Undang Nomor 25 Tahun 1999 tentang Perimbangan Keuangan antara Pemerintah Pusat dan Daerah, disebutkan bahwa sumber Pendapatan Asli Daerah terdiri dari:

1. Hasil Pajak daerah

Pajak daerah adalah iuran wajib yang dilakukan oleh orang pribadi atau badan kepada daerah tanpa imbalan langsung yang seimbang, yang dapat dipaksakan berdasarkan peraturan perundangundangan yang berlaku, yang digunakan untuk membiayai penyelenggaraan pemerintahan daerah dan pembangunan daerah.

2. Hasil Retribusi Daerah

Retribusi Daerah adalah pungutan daerah sebagai pembayaran atas jasa atau pemberian ijin tertentu yang khusus disediakan dan/atau diberikan oleh pemerintah daerah untuk kepentingan orang pribadi atau badan.

3. Hasil perusahaan milik daerah dan hasil pengelolaan kekayaan milik daerah lainnya yang dipisahkan, antara lain bagian laba, dividen, dan penjualan saham milik daerah.

4. Lain-lain Pendapatan Asli Daerah yang sah, antara lain berupa hasil penjualan aset tetap daerah dan jasa giro.

Berdasarkan uraian diatas dapat disimpulkan bahwa Pajak Hotel yang menjadi bahasan dalam artikel ini merupakan pajak daerah yang dalam hal pelaksanaannya mengacu pada UU Nomor 28 Tahun 2009 mengenai Pajak Daerah dan Restribusi Daerah didukung dengan Peraturan Daerah yang dikeluarkan oleh masing-masing kota. Sehubungan dengan lokasi penulisan artikel, maka peraturan pendukung yang digunakan adalah Peraturan Daerah Kota Surabaya Nomor 09 Tahun 2003 tentang Pajak Hotel dan

\section{TERMINOLOGI HOTEL}

Sesuai dengan UU No. 28 Tahun 2009 mengenai Pajak Daerah dan Restribusi Daerah, Pajak Hotel merupakan salah satu jenis Pajak Kabupaten/Kota yang diatur dengan Peraturan Daerah. Dalam hal ini penulis mengacu pada Peraturan Daerah (Perda) Kota Surabaya Nomor 09 Tahun 2003 tentang Pajak Hotel. Sebelum lebih jauh mengupas mengenai pajak atas jasa perhotelan, berikut merupakan definisi dari beberapa istilah yang akan berhubungan dengan pembahasan mengenai pajak atas jasa perhotelan. 
Menurut Peraturan Daerah Kota Surabaya No Tahun 2003:

- Hotel adalah bangunan yang khusus disediakan bagi orang untuk dapat menginap/ beristirahat, memperoleh bayaran, dan/atau fasilitas lainnya dengan dipungut bayaran, termasuk bangunan lainnya yang menyatu, dikelola dan dimiliki oleh pihak yang sama, kecuali untuk pertokoan dan perkantoran.

- Pengusaha Hotel, adalah orang atau badan hukum yang menyelenggarakan usaha hotel untuk dan atas namanya sendiri atau untuk dan atas nama pihak lain yang menjadi tanggungannya;

- Pembayaran, adalah jumlah yang diterima atau seharusnya diterima atas pelayanan sebagai pembayaran yang dilakukan oleh pengunjung kepada hotel

- Pajak Hotel, adalah pajak yang dipungut atas pelayanan yang disediakan dengan pembayaran kepada hotel

Sebelum lebih dalam mengupas mengenai pajak hotel, hal yang sering merancukan mengenai jenis pajak yang dikenakan atas jasa perhotelan ini adalah adanya konsep sewa dalam definisi hotel. Apabila dilihat dari definisi hotel diatas, maka dapat diartikan secara lebih sederhana yaitu bahwa hotel merupakan fasilitas yang dapat dinikmati oleh umum dengan memberikan pembayaran ataupun sewa. Hal ini seringkali menimbulkan pemikiran bahwa jasa perhotelan merupakan objek PPh Pasal 4 ayat 2 Final yang mengacu pada PP no 29 Tahun 1996 jo PP no 5 Tahun 2002. Namun kerancuan ini dapat dijernihkan apabila kita juga mencermati dan memahami Jasa di bidang Perhotelan yang diuraikan dalam UU No 42 Tahun 2009 Pasal 4A yang menyebutkan bahwa Jenis jasa di bidang perhotelan adalah meliputi:

a. Jasa penyewaan kamar, termasuk tambahannya di hotel, rumah penginapan, motel, losmen, hostel, serta fasilitas yang tekait dengan kegiatan perhotelan untuk tamu yang menginap; dan

b. Jasa penyewaan ruangan untuk kegiatan acara atau pertemuan di hotel, rumah penginapan, motel, losmen dan hostel.

Berdasarkan pengertian diatas, penyewaan ruangan untuk kegiatan acara atau pertemuan di hotel merupakan jasa di bidang perhotelan yang berarti bukanlah menjadi objek PPh Pasal 4 (2) Final melainkan merupakan objek Pajak Hotel. Namun akan berbeda penerapannya apabila penyewaan ruangan bukan untuk kegiatan acara atau pertemuan, misalnya menyewakan ruangan kepada Bank untuk digunakan sebagai kantor oleh bank bersangkutan atau kepada jasa penyedia layanan penerbangan, dimana kegiatan tersebut bisa dikategorikan sebagai objek PPN dan PPh Pasal 4 (2).

\section{NAMA, OBJEK, SUBJEK DAN DASAR PENGENAAN SERTA TARIF PAJAK}

Menurut Peraturan Daerah Kota Surabaya Nomor 09 Tahun 2003, Pajak Hotel adalah pajak yang dipungut atas setiap pelayanan yang disediakan dengan pembayaran di hotel. Pelayanan yang menjadi objek pajak yang dimaksud meliputi:

a. Fasilitas penginapan atau fasilitas tinggal jangka pendek, antara lain; gubuk pariwisata (cottage), motel, wisma pariwisata, pesanggrahan (hostel), losmen dan rumah penginapan termasuk rumah kos dengan jumlah kamar 10 (sepuluh) atau lebih yang menyediakan fasilitas seperti rumah penginapan; serta Apartemen, termasuk yang tidak berlokasi di lingkungan Hotel yang digunakan kurang dari satu bulan.

b. Pelayanan penunjang sebagai kelengkapan fasilitas penginapan atau tinggal jangka pendek yang sifatnya memberikan kemudahan dan kenyamanan. Antara lain telepon, faximil, telex, fotocopy, pelayanan cuci, setrika, taksi dan pengangkutan lainnya, yang disediakan atau dikelola hotel;

c. Fasilitas olahraga dan hiburan yang disediakan khusus untuk tamu hotel, bukan untuk umum antara lain Pusat Kebugaran (fitness center), kolam renang, tennis, golf, karaoke, pub, diskotik, yang disediakan atau dikelola hotel;

d. Jasa persewaan ruangan untuk kegiatan acara atau pertemuan di hotel;

Adapun yang tidak termasuk obyek pajak hotel adalah:

a. Penyewaan rumah atau kamar, apartemen dan atau fasilitas tempat tinggal lainnya yang tidak menyatu dengan hotel; dalam hal ini apartmen yang tidak termasuk objek pajak adalah apartemen yang digunakan lebih dari satu bulan dan tidak berlokasi di lingkungan Hotel.

b. Pelayanan tinggal di asrama, dan pondok pesantren.

c. Fasilitas olah raga dan hiburan yang disediakan dihotel yang dipergunakan oleh bukan tamu hotel dengan pembayaran.

d. Pertokoan, perkantoran, perbankan, salon yang dipergunakan oleh umum di hotel

e. Pelayanan perjalanan wisata yang diselenggarakan oleh hotel dan dapat dimanfaatkan oleh umum. 
Sehubungan dengan objek pajak yang telah diuraikan diatas dimana semuanya diatur dalam pasal 2, maka pada pasal 3 dinyatakan bahwa yang menjadi Subjek Pajak Hotel adalah orang pribadi atau badan yang melakukan pembayaran di hotel. Wajib Pajak Hotel adalah pengusaha hotel yang dalam hal ini menerima sejumlah pembayaran. Sehingga dapat disimpulkan yang dimaksud wajib pajak untuk pajak hotel adalah orang atau badan yang membayar atas pelayanan hotel dan pengusaha hotel. Dimana pembayar hotel merupakan wajib pajak tidak langsung, sedangkan bagi pengusaha hotel merupakan wajib pajak langsung karena merupakan wajib pungut. Pengusaha hotel itu berkewajiban menyetorkan Pajak Hotel ini ke kas daerah.

Dasar Pengenaan Pajak adalah Nilai berupa uang yang dijadikan Dasar untuk menghitung Pajak yang terutang. Dasar Pengenaan Pajak dalam Pajak Hotel ini adalah jumlah pembayaran yang dilakukan penyewa ataupun pengguna kepada hotel. Berdasarkan Pasal 35 UU No 28 Tahun 2009 mengenai Pajak Daerah dan Resribusi Daerah, disebutkan bahwa Tarif Pajak Hotel ditetapkan paling tinggi adalah sebesar $10 \%$ (sepuluh persen) dan selanjutnya tarif tersebut akan ditetapkan dengan Peraturan Daerah. Pokok pajak terutang dihitung dengan cara mengalikan tarif pajak (10\%) terhadap dasar pengenaan pajaknya.

Dalam tata cara pemungutan Pajak, Pengusaha Hotel harus menambahkan Pajak Hotel atas pembayaran pelayanan di Hotel dengan mengenakan tarif pajak. Apabila dalam pembayaran pelayanan di Hotel, pengusaha tidak menambahkan pajak atas pembayaran pelayanan maka dalam jumlah pembayaran dianggap telah termasuk Pajak Hotel.

\section{MASA PAJAK}

Pajak terutang dalam masa pajak terjadi pada saat pembayaran kepada Hotel sedangkan yang dimaksudkan dengan masa pajak adalah jangka waktu yang lamanya 1 (satu) bulan kalender. Dalam hal ini, setiap Wajib Pajak wajib memiliki Pembukuan dan Wajib Pajak wajib menerima, mengisi dan menyampaikan Surat Pemberitahuan Pajak Daerah (SPTPD) kepada Kepala Daerah selambat-lambatnya 15 (lima belas) hari setelah berakhirnya masa Pajak; Apabila SPTPD tidak disampaikan dalam jangka waktu yang telah dan telah ditegursecara tertulis, dikenakan sanksi administrasi berupa bunga sebesar $2 \%$ (dua persen) sebulan dihitung dari pajak yang kurang atau terlambat dibayar, untuk jangka waktu paling lama 24 (dua puluh empat) bulan dihitung sejak saat terutangnya ;Apabila kewajiban mengisi SPTPD tidak dipenuhi, pajak yangterutang dihitung secara jabatan, dan dikenakan sanksiadministrasi berupa kenaikan sebesar 25\% (dua puluh lima persen)dari pokok pajak ditambah sanksi administrasi berupa bungasebesar 2\% (dua persen) sebulan dihitung dari pajak yang kurangatau terlambat dibayar untuk jangka waktu paling lama 24 (duapuluh empat) bulan sejak saat terutangnya

\section{JATUH TEMPO DAN TATA CARA PEMBAYARAN}

Dalam pelaksanaannya, saat jatuh tempo pembayaran pajak ditetapkan oleh Kepala Daerah. Pembayaran pajak dilakukan di Kas Daerah atau tempat lain yang ditunjuk oleh Kepala Daerah sesuai waktu yang ditentukan dalamSKPD, SKPDKB, SKPDKBT dan STPD ;Pembayaran pajak dilakukan dengan menggunakan Surat Setoran Pajak Daerah (SSPD) dimana bentuk, jenis, isi dan ukuran Surat Setoran Pajak Daerah(SSPD) ditetapkan oleh Kepala Daerah

Pembayaran pajak harus dilakukan sekaligus atau lunas namun dalam kasus tertentu, Kepala Daerah dapat memberikan persetujuan untuk mengangsur pajak terutang dalam jangka waktu tertentu, setelah Wajib Pajak memenuhi persyaratan yang ditentukan ; Angsuran pembayaran pajak harus dilakukan secara teratur dan berurutan sesuai ketentuan yang berlaku, dengan dikenakan bunga sebesar 2\% (dua persen) sebulan dari jumlah pajak yang belum atau kurang dibayar; Kepala Daerah dapat memberikan persetujuan kepada Wajib Pajak untuk menunda pembayaran pajak sampai batas waktu yang ditentukan setelah memenuhi persyaratan yang ditentukan dengan dikenakan bunga 2\% (dua persen) sebulan dari jumlah pajak yang belum atau kurang dibayar ; Persyaratan untuk dapat mengangsur dan menunda pembayaran pajak serta tata cara pembayaran angsuran dan ditetapkan oleh Kepala Daerah.

\section{KESIMPULAN}

Jasa dalam bidang perhotelan yang meliputi penyewaan kamar dan fasilitas hotel yang dapat dinikmati oleh masyarakat umum dengan memberikan kontrapretasi berupa pembayaran merupakan objek Pajak Daerah dan bukan merupakan objek Pajak Penghasilan Pasal 4 (2) Final. Namun hal ini akan tidak berlaku apabila penyewaan tersebut merupakan penyewaan ruang yang dipunyai oleh hotel namun bukan merupakan fasilitas dari jasa perhotelan sehingga kegiatan penyewaan yang demikian akan menjadi objek Pajak Pertambahan Nilai dan Pajak Penghasilan Pasal 4 (2). 


\section{DAFTAR PUSTAKA}

Mardiasmo, 2009. Perpajakan, edisi revisi 2009. Yogyakarta: Penerbit Andi.

Peraturan Daerah Kota Surabaya Nomor 09 Tahun 2003 tentang Pajak Hotel.

Peraturan Pemerintah No 29 Tahun 1996 jo Peraturan Pemerintah No 5 Tahun 2002.
Undang-Undang Republik Indonesia Nomor 28 Tahun 2009 tentang Pajak Daerah dan Restribusi Daerah.

Undang-Undang Republik Indonesia Nomor 42 Tahun 2009 tentang Perubahan ketiga atas Undang-Undang Nomor 8 Tahun 1983 tentang Pajak Pertambahan Nilai Barang dan Jasa dan Pajak Penjualan atas Barang Mewah 